\title{
SISTEM DESENTRALISASI DALAM NEGARA KESATUAN REPUBLIK INDONESIA PERSPEKTIF YURIDIS KONSTITUSIONAL
}

\author{
Reynold Simandjuntak \\ Universitas Negeri Menado \\ reynoldsim72@yahoo.com
}

\begin{abstract}
Abstrak
Unitary state is the foundation of understanding the limits of the contents of autonomy. Selection of a form of state will be very closely related to the social structure and ethnic communities in the country. The principle of unity is needed because of the diversity of ethnicity, race, religion, and culture inherited by the Indonesian nation in the history of Indonesian nation requires united with as tight-tightly in diversity. Unitary Republic of Indonesia is divided into areas of the province. The provincial areas divided over the districts and areas of the city. Each provincial, district and local government areas of the city have regulated by law. The provincial, district, and the city set up and manage their own affairs in accordance with the principle of autonomy and duty of assistance.

Negara kesatuan merupakan landasan batas dari isi pengertian otonomi. Pemilihan sebuah bentuk negara akan sangat erat kaitannya dengan struktur sosial dan etnisitas masyarakat yang ada dalam negara tersebut. Prinsip persatuan sangat dibutuhkan karena keragaman suku, bangsa, agama, dan budaya yang diwarisi oleh bangsa Indonesia dalam sejarah mengharuskan bangsa indonesia bersatu dengan seerat-eratnya dalam keragaman. Negara Kesatuan Republik Indonesia dibagi atas daerah-daerah provinsi. Daerah provinsi itu dibagi lagi atas daerah kabupaten dan daerah kota. Setiap daerah provinsi, daerah kabupaten, dan daerah kota mempunyai pemerintahan daerah yang diatur dengan undang-undang. Pemerintahan daerah provinsi, daerah kabupaten, dan kota mengatur dan mengurus sendiri urusan pemerintahan menurut asas otonomi dan tugas pembantuan.
\end{abstract}

Kata Kunci: Negara kesatuan, otonomi, desentralisasi

Pasal 18 ayat (1) Undang-Undang Dasar Negara Republik Indonesia 1945 (UUD NRI 1945) menyebutkan bahwa “Negara Indonesia dibagi atas daerah-daerah provinsi dan daerah provinsi itu dibagi atas kabupaten dan kota, yang tiap-tiap provinsi, kabupaten dan kota itu mempunyai pemerintahan daerah, yang diatur dengan Undang-Undang". Sedangkan Pasal 18 UUD 19945 ayat (2) sebagai ground norm dari pemerintahan daerah secara tegas menyatakan: "Pemerintah provinsi, kota/ kabupaten, mengatur, dan mengurus sendiri urusan pemerintahan menurut asas otonomi dan tugas pembantuan." Penyelenggaraan pemerintahan daerah kemudian dilakukan berdasar prinsip otonomi seluas-luasnya, kecuali urusan pemerintahan yang oleh undang-undang ditentukan sebagai urusan Pemerintah Pusat.

Sesuai dengan amanat Undang-Undang Dasar Negara Republik Indonesia Tahun 1945, pemerintah daerah berwenang untuk mengatur dan mengurus sendiri urusan pemerintahan menurut asas otonomi dan tugas pembantuan. 
Pemberian otonomi luas kepada daerah diarahkan untuk mempercepat terwujudnya kesejahteraan masyarakat melalui peningkatan pelayanan, pemberdayaan dan peran serta masyarakat. Di samping itu melalui otonomi luas, daerah diharapkan mampu meningkatkan daya saing dengan memperhatikan prinsip demokrasi, pemerataan, keadilan, keistimewaan dan kekhususan serta potensi dan keanekaragaman daerah dalam sistem Negara Kesatuan Republik Indonesia.

Memperbincangkan hubungan pusat dan daerah dalam bingkai negara kesatuan cukup menarik untuk dikaji. Masalah yang timbul dalam prakteknya yaitu mengenai tarikmenarik kepentingan jelas merupakan hal yang tidak dapat dihindarkan. Untuk negara kesatuan, upaya pemerintah pusat untuk selalu memegang kendali atas berbagai urusan pemerintahan sangat jelas. Kelaziman negara yang berbentuk kesatuan pemegang otoritas pemerintahan adalah pusat. Kewenangan yang diberikan oleh pusat kepada daerah sangat terbatas. ${ }^{1}$

Negara kesatuan adalah sebuah negara yang diperintah sebagai satu kesatuan. Kekuasaan politik pemerintah dalam negara kesatuan dapat dialihkan ke tingkat yang lebih rendah yang dipilih rakyat setempat, misalnya gubernur atau walikota, tapi pemerintah pusat memiliki hak untuk mencabut pejabat-pejabat tersebut. Hal ini berbeda dengan negara federasi, di mana setiap negara bagian memiliki kekuasaan sendiri yang tidak dapat dicabut pemerintah federal. $^{2}$

Pendapat C.F. Strong yang dikutip Miriam Budiardjo $^{3}$ menyatakan bahwa ciri mutlak yang melekat pada negara kesatuan ialah: pertama, adanya supremasi dari dewan perwakilan rakyat pusat, dan kedua, tidak adanya badanbadan lain yang berdaulat.

\footnotetext{
${ }^{1}$ Ni'matul Huda, Hukum Pemerintahan Daerah, (Bandung: Nusamedia, 2010), h. 1

${ }^{2}$ Negara Kesatuan, https://id.wikipedia.org/wiki/ Negara_kesatuan, diakses tanggal 7 April 2015

${ }^{3}$ Miriam Budiharjo, Dasar-dasar Ilmu Politik, (Jakarta: Gramedia, 2000), h. 140.
}

Kekuasaan pemerintah dalam suatu negara yang berbentuk kesatuan seperti itu dapat diselenggarakan dengan cara terhimpun/ ditumpuk (gathered) secara sentralisasi (centralized) ${ }^{4}$, sehingga segala urusan dalam negara terletak di tangan pemerintah pusat (central government), dan semua kewenangan pemerintah dilakukan oleh satu pusat pemerintahan (single centralized government), atau oleh pusat bersama-sama dengan organnya yang berada/ dipencarkan di daerah-daerah. ${ }^{5}$ Pemencaran organ-organ yang menjalankan kewenangan pemerintah pusat di daerah-daerah seperti itu, menurut Bagir Manan dikenal sebagai dekonsentrasi (centralisatie met de deconcentratie), di mana semua kewenangan menyelenggarakan pemerintahan daerah, termasuk kewenangan organ-organ dalam membentuk peraturan perundang-undangan didasarkan atau sangat tergantung pada pemerintah (pusat). ${ }^{6}$

Negara Kesatuan adalah negara yang pemerintah pusat atau nasional memegang kedudukan tertinggi, dan memiliki kekuasaan penuh dalam pemerintahan sehari-hari. Tidak ada bidang kegiatan pemerintah yang diserahkan konstitusi kepada satuan-satuan pemerintahan yang lebih kecil (dalam hal ini, daerah atau provinsi). Menurut negara Kesatuan, pemerintah pusat (nasional) bisa melimpahkan banyak tugas (melimpahkan wewenang) kepada kota-kota, kabupatenkabupaten, atau satuan-satuan pemerintahan lokal. Namun, pelimpahan wewenang ini hanya diatur oleh undang-undang yang dibuat parlemen pusat (di Indonesia DPR-RI), bukan diatur di dalam konstitusi (di Indonesia UUD 1945), di mana pelimpahan wewenang tersebut bisa saja ditarik sewaktu-waktu.

Pemerintah pusat mempunyai wewenang untuk menyerahkan sebagian kekuasaannya kepada daerah berdasarkan hak otonomi, di

${ }^{4}$ Abu Daud Busroh, Ilmu Negara, (Jakarta: Bumi Aksara, 2001), h. 145-146.

${ }^{5}$ Martin H. Hutabarat (eds), Hukum dan Politk Indonesia: Tinjauan Analitis Dekrit Presiden Dan Otonomi Daerah, (Jakarta: Pustaka SInar Harapan Jakarta, 1996), h. 140.

${ }^{6}$ F. Isjwara, Pengantar Ilmu Politik, (Bandung: Bina Cipta, 1980), h. 212-213. 
mana ini dikenal pula sebagai desentralisasi. Namun, kekuasaan tertinggi tetap berada di tangan pemerintah pusat dan dengan demikian, baik kedaulatan ke dalam maupun kedaulatan ke luar berada pada pemerintah pusat.

Miriam Budiardjo menulis bahwa yang menjadi hakekat negara kesatuan adalah kedaulatannya tidak terbagi dan tidak dibatasi, di mana hal tersebut dijamin di dalam konstitusi. Meskipun daerah diberi kewenangan untuk mengatur sendiri wilayahnya, tetapi itu bukan berarti pemerintah daerah itu berdaulat, sebab pengawasan dan kekuasaan tertinggi tetap berada di tangan pemerintah pusat. Pemerintah pusat-lah sesungguhnya yang mengatur kehidupan setiap penduduk daerah. ${ }^{7}$

Keuntungan negara kesatuan adalah adanya keseragaman Undang-Undang, karena aturan yang menyangkut 'nasib' daerah secara keseluruhan hanya dibuat oleh parlemen pusat. Namun, negara Kesatuan bisa tertimpa beban berat oleh sebab adanya perhatian ekstra pemerintah pusat terhadap masalah-masalah yang muncul di daerah.

Penanganan setiap masalah yang muncul di daerah kemungkinan akan lama diselesaikan oleh sebab harus menunggu instruksi dari pusat terlebih dahulu. Bentuk negara kesatuan juga tidak cocok bagi negara yang jumlah penduduknya besar, heterogenitas (keberagaman) budaya tinggi, dan yang wilayahnya terpecah ke dalam pulau-pulau. Ada sebagian kewenangan yang didelegasikan pemerintah pusat kepada pemerintah daerah, yang dengan kewenangan tersebut pemerintah daerah mengatur penduduk yang ada di dalam wilayahnya. Namun, pengaturan pemerintah daerah terhadap penduduk di wilayahnya lebih bersifat 'instruksi dari pusat' ketimbang improvisasi dan inovasi pemerintah daerah itu sendiri.

Pemerintah pusat dalam negara kesatuan, secara langsung mengatur masing-masing penduduk yang ada di setiap daerah. Misalnya, pemerintah pusat berwenang menarik pajak dari penduduk daerah, mengatur kepolisian

${ }^{7}$ Miriam Budiardjo, Dasar-dasar..., h. 63 daerah, mengatur badan pengadilan, membuat kurikulum pendidikan yang bersifat nasional, merelay stasiun televisi dan radio pemerintah ke seluruh daerah, dan bahkan menunjuk gubernur kepala daerah.

\section{Sistem Desentralisasi}

Desentralisasi merupakan suatu istilah yang secara etimologis merupakan bahasa Latin yang terdiri dari kata de berarti lepas, dan centrum berarti pusat, sehingga bila diartikan, desentralisasi berarti melepaskan diri dari pusat. ${ }^{8}$ Maksud pengertian tersebut bukan berarti daerah dapat berdiri sendiri melepaskan diri dari ikatan negara, tetapi dari sudut ketatanegaraan, desentralisasi berarti pelimpahan kekuasaan pemerintahan dari pemerintah pusat kepada daerah-daerah untuk mengurus rumah tangganya sendiri ${ }^{9}$, dengan kata lain, daerah diberikan otonomi untuk menjadi daerah otonom.

Terkait dengan pengertian desentralisasi tersebut, Logemann mengemukakan, desentralisasi berarti adanya kekuasaan bertindak merdeka (vrije beweging) yang diberikan kepada satuan-satuan kenegaraan yang memerintah sendiri daerahnya itu, yaitu kekuasaan yang berdasarkan inisiatif sendiri yang disebut otonomi, yang oleh Van Vollenhoven dinamakan eigenmeesterschap. ${ }^{10}$ Wesber sebagaimana dikutip Bayu Surianingrat ${ }^{11}$, menyebutkan bahwa "to decentralize means to devide and distribute, as governmental administration, to withdraw from the center or place of concentration" yang artinya bahwa desentralisasi berarti membagi dan mendistribusikan, misalnya administrasi pemerintahan, mengeluarkan dari pusat atau tempat konsentrasi. Sedangkan Philip

\footnotetext{
${ }^{8}$ Koesoemahatmadja, Pengantar ke Arah Sistem Pemerintahan Daerah di Indonesia, (Bandung: Bina Cipta, 1979), h. 14.

${ }^{9}$ Victor Situmorang, Hukum Administrasi Pemerintahan di Daerah, (Jakarta:Sinar Grafika, 1994), h. 38.

${ }^{10}$ E. Utrecht, Pengantar Dalam Hukum Indonesia, (Jakarta: Ichtiar,1966), hlm. 47.

${ }^{11}$ Bayu Surianingrat, Desentralisasi dan Dekonsentrasi Pemerintahan di Indonesia, Suatu Analisa, (Jakarta: Dewaruci Press, 1981), h. 3.
} 
Mawhood ${ }^{12}$ mengartikan desentralisasi sebagai devolution of power from central government to local government.

Menurut pandangan Joeniarto ${ }^{13}$, desentralisasi dimaksudkan untuk memberikan wewenang dari pemerintah negara kepada pemerintah lokal untuk mengatur dan mengurus urusan tertentu sebagai urusan rumah tangganya sendiri. Lain halnya dengan Irawan Sujito ${ }^{14}$, menyebutkan bahwa desentralisasi adalah pelimpahan kewenangan Pemerintah kepada pihak lain untuk dilaksanakan. Sedangkan Amrah Muslimin ${ }^{15}$ mengatakan bahwa desentralisasi merupakan pelimpahan kewenangan-kewenangan oleh pemerintah pusat pada badan-badan otonom (swatantra) yang berada di daerah-daerah.

Otonomi daerah merupakan esensi pemerintahan desentralisasi. Istilah otonomi berasal dari penggalan dua kata bahasa yunani, yakni autos yang berarti sendiri dan nomos yang berarti undang-undang. Otonomi bermakna membuat perundang-undangan sendiri (zelfwetgeving), namun dalam perkembangannya konsepsi otonomi daerah selain mengandung arti zelfwetgeving (membuat perda-perda), juga utamanya mencakup zelfbestuur (pemerintahan sendiri). C.W. vander pot memahami konsep otonomi daerah sebagai eigen huishouding (menjalankan rumah tangganya sendiri ${ }^{16}$. Dalam kamus on line wikipedia, otonomi daerah dapat diartikan sebagai kewajiban yang diberikan kepada daerah otonom untuk mengatur dan mengurus sendiri urusan pemerintahan dan kepentingan masyarakat setempat menurut aspirasi masyarakat untuk meningkatkan daya guna dan hasil guna penyelenggaraan pemerintahan dalam rangka pelayanan terhadap masyarakat dan pelaksanaan pembangunan

${ }^{12}$ Philip Mawhood, Local Government in the Third World, (Chicester, UK: John Wisley and Sons, 1983), h. 23.

${ }^{13}$ Joeniarto, Perkembangan Pemerintahan Lokal, (Jakarta: Bumi Aksara, 1992), h. 15.

${ }^{14}$ Irawan Sujito, Hubungan Pemerintah Pusat dan Pemerintah Daerah, (Jakarta: Rineka Cipta, 1990), h. 29.

${ }^{15}$ Amrah Muslimin, Aspek-aspek Hukum Otonomi Daerah, (Bandung: Alumni, 1986), h. 42.

${ }^{16}$ Ni'matul Huda, Hukum Pemerintahan..., h. 83. sesuai dengan peraturan perundang-undangan ${ }^{17}$. Sedangkan pengertian otonomi daerah menurut UU No.32 Tahun 2004 adalah hak, wewenang, dan kewajiban daerah otonom untuk mengatur dan mengurus sendiri urusan pemerintahan dan kepentingan masyarakat setempat sesuai dengan peraturan perundang-undangan ${ }^{18}$.

Lain halnya dengan Hossein yang mengungkapkan bahwa local government merupakan sebuah konsep yang dapat mengandung tiga arti, berarti pemerintahan lokal yang seringkali dipertukarkan dengan local authorithy yang mengacu pada organ yakni council dan mayor dimana rekrutmen pejabatnya didasarkan pada pemilihan ${ }^{19}$. Kedua mengacu pada pemerintahan lokal yang dilakukan oleh pemerintahan lokal. Arti kedua ini lebih mengacu pada fungsi ${ }^{20}$. Ketiga bermakna daerah otonom. Hossein menjelaskan bahwa pwmbentukan darah otonom yang secara simultan merupakan kelahiran status otonomi berdasarkanatas aspirasi dan kondisis objektif dari masyarakat yang berada diwilayah tertentu sebagai bagian dari bangsa dan wilayah nasional. Masyarakat yang menuntut otonomi melalui desentralisasi menjelma menjadi daerah otonom sebagai kesatuan masyarakat hukum yang berwenang mengatur dan menangani urusan pemerintahan menurut prakarsa sendiri berdasarkan aspirasi masyarakat. ${ }^{21}$

Otonomibukanlahsebuah proses pemerdekaan daerah yang dalam arti kemerdekaan (kedaulatan yang terpisah) atau otonomi tidak dapat diartikan sebagai adanya kebebasan penuh secara absolute dari suatu daerah karena otonomi adalah suatu proses untuk memberikan kesempatan kepada daerah untuk bisa berkembang sesuai dengan potensi yang mereka miliki, dengan demikian

${ }^{17}$ Otonomi Daerah, https://id.wikipedia.org/wiki/ Otonomi_daerah, diakses tanggal 7 Maret 2015

${ }^{18}$ Pheni Chalid, Otonomi Daerah : Masalah, Pemberdayaan dan Konflik, (Jakarta : Kemitraan, 2005), h 21

${ }^{19}$ M.R. Khairul Muluk, Desentralisasi dan Pemerintah Daerah, (Malang: Bayumedia Publishing, Cet 2, 2007), h. 10

${ }^{20}$ M.R. Khairul Muluk, Desentralisasi..., h. 10

${ }^{21}$ M.R. Khairul Muluk, Desentralisasi..., h. 10 
otonomi harus bermakna sebagai jalan untuk mengoptimalisasikan segala potensi lokal, baik alam, lingkungan maupun kebudayaan. Dan optimalisasi bukanlah eksploitasi, melainkan sebuah proses yang memungkinkah daerah bisa mengembangkan diri dan mengubah kehidupan masyarakat daerah menjadi lebih baik ${ }^{22}$.

Desentralisasi merupakan pengotonomian, yakni proses memberikan otonomi kepada masyarakat dalam wilayah tertentu. Desentralisasi dan otonomi daerah merupakan dua sisi dari satu mata uang. Kaitan desentralisasi dan otonomi daerah ini dinyatakan oleh Gerald S. Maryanov. ${ }^{23}$

G. Shabbir Cheema dan Dennis A. Rondinelli ${ }^{24}$, merumuskan definisi desentralisasi dengan lebih merujuk pada prespektif yang lebih luas dan fleksibel. Menurut mereka, desentralisasi adalah perpindahan perencanaan, pengambilan keputusan, atau kewenangan administratif dari pemerintah pusat ke organisasi bidangnya, unit administratif daerah, semi otonomi dan organisasi parastatal, pemerintahan daerah, atau organisasi-organisasi nonpemerintah (the transfer of planning, decision-making, or administrative authority from central government to its field organization, lokal administrative units, semi autonomous and parastatal organisations, lokal government, or non-government organizations)

Dalam kaitan itu, G. Shabbir Cheema dan Dennis A. Rondinelli ${ }^{25}$ membagi empat tipe desentralisasi, yaitu; deconcentration, delegation, devolution, and privatization. Pengertiannya antara lain sebagai berikut: a) Dekonsentrasi diartikan distribusi wewenang administrasi di dalam struktur pemerintahan; b) Delegasi

${ }^{22}$ Tim Lapera, Otonomi Pemberian Negara,Kajian Kritis Atas Kebijakan Otonomi Daerah, (Jakarta : Lapera Pustaka Utama, 2001), h. 154-155

${ }^{23}$ Pheni Chalid, Otonomi Daerah..., h.17.

${ }^{24} \mathrm{G}$. Shabbir Cheema and Dennis A. Rondinelli, (ed.), Decentralization and Development, Policy Implementation in Developing Countries (London/New Dehli: Sage Publication/Baverly Hills, 1992), h. 18.

${ }^{25}$ S.N. Jha and HAL.C. Mathur (ed.), Decentralization and Lokal Politics, (New Delhi/ London: Sage Publications/ Thousand Oaks, 1999), h. 55-56. adalah pendelegasian otoritas manajemen dan pengambilan keputusan atau fungsifungsi tertentu yang sangat spesifik, kepada organisasi-organisasi yang secara langsung tidak di bawah kontrol pemerintah; dan c) Devolusi adalah penyerahan fungsi dan otoritas dari pemerintah pusat kepada daerah otonom, swastanisasi adalah penyerahan beberapa otoritas dalam perencanaan dan tanggung jawab administrasi tertentu kepada organisasi swasta.

Selain penggolongan tipe desentralisasi sebagaimana tersebut diatas, John M. Cohen dan Stephen B. Peterson ${ }^{26}$ membedakan desentralisasi dengan menggunakan 6 (enam) pendekatan, yaitu: 1) Basic of historical origins (berdasarkan kepada sejarah); 2) By hierarchy and function (berdasarkan hirarki dan fungsi); 3) By problem being addressed and the values of the investigation (berdasarkan masalah-masalah yang muncul dan nilai-nilai penyelidikan); 4) Focus on patterns of administrative structures and functions that are responsible for the production and provision of collective goods and services (difokuskan pada pola-pola struktur administratif dan fungsi-fungsi yang bertanggung jawab pada hasil dan ketentuan-ketentuan dari pelayanan dan barang); 5) Typically based on the experience of a single country (tipe yang didasarkan pada pengalaman suatu negara tertentu); dan on basis of objectives (berdasarkan pada tujuannya).

Kaitan antara desentralisasi khususnya otonomi dengan dasar kedaulatan rakyat atau kerakyatan telah pula ditegaskan oleh Mohammad Hatta. Ia menyatakan:27 "berdasarkan kedaulatan rakyat, rakyat mempunyai hak untuk menentukan nasib tidak hanya ada pada pucuk pemerintahan negeri, melainkan juga pada tiap tempat (di kota, desa dan daerah). Tiap-tiap golongan persekutuan mempunyai badan perwakilan sendiri (seperti Gemeenteraad Provinciale Raad, dan lain-lainnya). Sehingga tiap-tiap bagian atau golongan

\footnotetext{
${ }^{26}$ John MCohen and Stepen B. Peterson, Adminitrative Desentralization, (Connecticut, USA: Kumarian Press, 1999), h. 20-22.

${ }^{27}$ Mohammad Hatta, Ke arah Indonesia Merdeka (1932), jilid I, (Jakarta: Bulan Bintang, 1976), h. 103.
} 
rakyat mendapat autonomi (membuat dan menjalankan peraturan sendiri) dan zelfbestuur (menjalankan peraturan-peraturan yang dibuat oleh dewan yang lebih tinggi). Sehingga bukan saja persekutuan yang besar mempunyai hak untuk menentukan nasibnya sendiri, melainkan rakyat semuanya, juga tiap-tiap bagian dari negeri atau bagian dari rakyat yang banyak. Keadaan yang seperti ini penting sekali, karena keperluan setiap tempat dalam suatu negara berbeda-beda".

Lain halnya dengan Hossein yang mengungkapkan bahwa local government merupakan sebuah konsep yang dapat mengandung tiga arti, berarti pemerintahan lokal yang seringkali dipertukarkan dengan local authorithy yang mengacu pada organ yakni council dan mayor dimana rekrutmen pejabatnya didasarkan pada pemilihan ${ }^{28}$. Kedua mengacu pada pemerintahan lokal yang dilakukan oleh pemerintahan lokal. Arti kedua ini lebih mengacu pada fungsi ${ }^{29}$. Ketiga bermakna daerah otonom. Hossein menjelaskan bahwa pwmbentukan darah otonom yang secara simultan merupakan kelahiran status otonomi berdasarkanatas aspirasi dan kondisis objektif dari masyarakat yang berada diwilayah tertentu sebagai bagian dari bangsa dan wilayah nasional. Masyarakat yang menuntut otonomi melalui desentralisasi menjelma menjadi daerah otonom sebagai kesatuan masyarakat hukum yang berwenang mengatur dan menangani urusan pemerintahan menurut prakarsa sendiri berdasarkan aspirasi masyarakat ${ }^{30}$.

Otonomibukanlahsebuah proses pemerdekaan daerah yang dalam arti kemerdekaan (kedaulatan yang terpisah) atau otonomi tidak dapat diartikan sebagai adanya kebebasan penuh secara absolute dari suatu daerah karena otonomi adalah suatu proses untuk memberikan kesempatan kepada daerah untuk bisa berkembang sesuai dengan potensi yang mereka miliki, dengan demikian otonomi harus bermakna sebagai jalan untuk mengoptimalisasikan segala potensi lokal, baik

\footnotetext{
${ }^{28}$ M.R. Khairul Muluk, Desentralisasi..., h. 10

${ }^{29}$ M.R. Khairul Muluk, Desentralisasi..., h. 10

${ }^{30}$ M.R. Khairul Muluk, Desentralisasi..., h. 10
}

alam, lingkungan maupun kebudayaan. Dan optimalisasi bukanlah eksploitasi, melainkan sebuah proses yang memungkinkah daerah bisa mengembangkan diri dan mengubah kehidupan masyarakat daerah menjadi lebih baik. ${ }^{31}$.

\section{Desentralisasi Dalam Negara Kesatuan Republik Indonesia}

Negara Kesatuan Republik Indonesia dibagi atas daerah-daerah provinsi. Daerah provinsi itu dibagi lagi atas daerah kabupaten dan daerah kota. Setiap daerah provinsi, daerah kabupaten, dan daerah kota mempunyai pemerintahan daerah yang diatur dengan undang-undang. Pemerintahan daerah provinsi, daerah kabupaten, dan kota mengatur dan mengurus sendiri urusan pemerintahan menurut asas otonomi dan tugas pembantuan. ${ }^{32}$

Pemerintah daerah menjalankan otonomi seluas-luasnya, kecuali urusan pemerintahan yang oleh undang-undang ditentukan sebagai urusan Pemerintah Pusat. Pemerintahan daerah berhak menetapkan peraturan daerah dan peraturan-peraturan lain untuk melaksanakan otonomi dan tugas pembantuan. Susunan dan tata cara penyelenggaraan pemerintahan daerah diatur dalam undang-undang.

Pemerintahan daerah provinsi, daerah kabupaten, dan kota memiliki Dewan Perwakilan Rakyat Daerah yang anggota-anggotanya dipilih melalui pemilihan umum. Gubernur, Bupati, dan Walikota masing-masing sebagai Kepala Pemerintah Daerah Provinsi, Kabupaten dan Kota dipilih secara demokratis.

Hubungan wewenang antara pemerintah pusat dan pemerintah daerah provinsi, kabupaten, dan kota atau antara provinsi dan kabupaten dan kota, diatur dengan undang-undang dengan memperhatikan kekhususan dan keragaman daerah. Hubungan keuangan, pelayanan umum, pemanfatan sumber daya alam dan sumber daya lainnya antara pemerintah pusat dan pemerintahan daerah diatur dan dilaksanakan

\footnotetext{
${ }^{31}$ Tim Lapera, Otonomi Pemberian..., h. 154-155

${ }^{32}$ Lihat lebih lanjut lihat ketentuan Pasal 18 UUD RI Tahun 1945
} 
secara adil dan selaras berdasarkan undangundang.

Negara mengakui dan menghormati satuansatuan pemerintahan daerah yang bersifat khusus atau bersifat istimewa yang diatur dengan undang-undang. Negara mengakui dan menghormati kesatuan-kesatuan masyarakat hukum adat serta hak-hak tradisonalnya sepanjang masih hidup dan sesuai dengan perkembangan masyarakat dan prinsip Negara Kesatuan Republik Indonesia, yang diatur dalam undang-undang. ${ }^{33}$

Indonesia merupakan negara yang sudah pernah beberapa kali mengalami pergantian bentuk dan sistem pemerintahan, mulai dari bentuk negara Federal, Kesatuan atau sistem pemerintahan yang parlementer, SemiPresidensiil, dan Presidensiil. Terpaku pada Pancasila terutama sila ketiga yang berbunyi "Persatuan Indonesia", Indonesia adalah negara yang pada dasarnya mementingkan rasa kesatuan di dalam bernegara, "Bhineka Tunggal Ika" berbeda-beda namun tetap satu.

Apabila dilihat ke dalam UUD 1954 Pasal 1 ayat (1), negara Indonesia secara tegas dinyatakan sebagai suatu negara kesatuan yang berbentuk Republik. Prinsip pada negara kesatuan ialah bahwa yang memegang tampuk kekuasaan tertinggi atas segenap urusan negara ialah pemerintah pusat tanpa adanya suatu delegasi atau pelimpahan suatu kekuasaan kepada Pemerintah Daerah (Local Goverment). ${ }^{34}$ Dalam negara kesatuan terdapat asas bahwa segenap urusan-urusan negara tidak dibagi antara pemerintah pusat dengan pemerintah lokal sedemikian rupa, sehingga urusan-urusan negara dalam negara kesatuan tetap merupakan suatu kebulatan (eenheid) dan bahwa pemegang kekuasaan tertinggi di negara itu ialah pemerintah pusat.

\footnotetext{
${ }^{33}$ Lihat Pasal 18 UUD RI Tahun 1945

${ }^{34} \mathrm{M}$. Solly Lubis, Pergeseran Garis Politik dan Perundang-undangan Mengenai Pemerintah Daerah, Alumni, Bandung, 1983, h. 8
}

\section{NEGARA KESATUAN REPUBLIK INDONESIA MENURUT UUD NRI 1945}

Negara Indonesia adalah negara kesatuan yang berbentuk Republik

(Pasal 1 ayat (1))

Negara Kesatuan Republik Indonesia dibagi atas daerah-daerah propinsi dan daerah provinsi itu dibagi atas kabupaten dan kota, yang tiap-tiap provinsi, kabupaten dan kota itu mempunyai pemerintahan daerah, yang diatur dengan undangundang

(Pasal 18 ayat (1))

Negara mengakui dan menghormati satuan-satuan pemerintahan daerah yang bersifat khusus atau bersifat istimewa yang diatur dengan undangundang

(Pasal 18B ayat (1))

Negara mengakui dan menghormati kesatuankesatuan masyarakat hukum adat beserta hak-hak tradisionalnya sepanjang masih hidup dan sesuai dengan perkembangan masyarakat dan prinsip Negara Kesatuan Republik Indonesia, yang diatur dalam undang-undang

(pasal 18B ayat (2))

Negara Kesatuan Republik Indonesia adalah sebuah negara kepulauan yang berciri nusantara dengan wilayah yang batas-batas dan hak-haknya ditetapkan dengan undang-undang

khusus mengenai bentuk Negara Kesatuan Republik Indonesia tidak dapt dilakukan perubahan

(Pasal 37 ayat (5))

Di dalam negara kesatuan tanggung jawab pelaksanaan tugas-tugas pemerintahan pada dasarnya tetap berada di tangan pemerintah pusat. Akan tetapi karena sistem pemerintahan indonesia salah satunya menganut asas negara kesatuan yang didesentralisasikan, maka ada tugas-tugas tertentu yang diurus sendiri, sehingga menimbulkan hubungan timbal balik yang melahirkan adanya hubungan kewenangan dan pengawasan. ${ }^{35}$

Negara kesatuan merupakan landasan batas dari isi pengertian otonomi. Berdasarkan landasan batas tersebut dikembangkanlah berbagai peraturan (rules) yang megatur mekanisme yang akan menjelmakan keseimbangan antara tuntutan kesatuan dan tuntutan ekonomi. Di sini pula letak kepentingan spanning yang timbul dari kondisi tarik menarik antara kedua kecenderungan tersebut. ${ }^{36}$

\footnotetext{
${ }^{35} \mathrm{Ni}$ 'matul Huda, Hukum Pemerintahan..., h. 43

${ }^{36}$ Bagir Manan, Perjalanan Historis Pasal 18 UUD 1945, (Jakarta: UNISKA, 1993), h. 3
} 
Belakangannegeri inimengalami pergunjingan mengenai bentuk negara kita tercinta ini. Ada yang menganggap bahwa negeri kita ini memiliki daerah yang luas sehingga lebih memungkinkan bagi kita untuk menggunakan sistem bentuk negara federal yang salah satu ciri utamanya adalah memiliki daerah wilayah yang luas. Tapi ada juga yang menganggap hal itu bertentangan dengan dasar negara kita yaitu Pancasila dan UUD 1945 yang lebih condong mementingkan persatuan dan kesatuan bangsa.

Maraknya berbagai tuntutan perubahan untuk meninggalkan bentuk negara kesatuan dan beralih ke federalisme, menurut Buyung Nasution $^{37}$ lebih disebabkan oleh kenyataan telah terdistorsinya konsep kesatuan (unitary) menjadi "persatuan dan kesatuan", yang lebih dekat kepada peyeragaman (uniform). Akibatnya, berbagai perbedaan yang ada tidak dilihat sebagai aneka kekayaan dalam rangka kebhinekaan, melainkan lebih dilihat sebagai potensi ancaman yang karenanya harus ditundukkan di bawah "persatuan dan kesatuan" melalui sentralisasi kekuasaan. Menurut gagasan Harun Alrasid kemunculan gagasan negara serikat dipicu oleh sentralisasi pemerintahan yang dianggap berlebihan ( $a$ higly cenralized goverment), juga mengenai hubungan keuangan antara pusat dan daerah yang dianggap kurang adil (soal persentase yang merugikan negara). ${ }^{38}$

Menurut pandangan Afan Gaffar dkk, pilhan negara kesatuan sebagai bentuk negara merupakan pilihan yang tepat ketimbang federalisme karena format pemerintahan negara yang federalistik memerlukan persyaratan tertentu untuk mewujudkannya dalam kehidupan sebuah negara. Di samping itu, pemilihan sebuah bentuk negara akan sangat erat kaitannya dengan struktur sosial dan etnisitas masyarakat yang ada dalam negara tersebut. Sebuah negara yang sangat tinggi tingkat homogenitasnya tidak sulit

\footnotetext{
${ }^{37}$ Adnan Buyung Nasution, Arus Pemikiran Konstitusionalisme, (Jakarta: Kasta Hasta Pustaka, 2007), h. 131

${ }^{38}$ Adnan Buyung Nasution dkk, Federalisme Untuk Indonesia (Jakarta: Kompas, 1999), h. 9
}

mempraktekkan federalisme, terutama yang menyangkut derajad pembilahan sosialnya. Sebaliknya, dalam masyarakat yang sangat tinggi tingkat fragmentasi sosialnya, maka diperlukan sebuah pemerintahan nasional yang kuat. Selain itu, format politik dalam sebuah negara juga ikut menentukan terhadap pilihan atas bentuk negara yaitu yang menyangkut derajad demokrasi dari negara tersebut. ${ }^{39}$

Prinsip persatuan sangat dibutuhkan karena keragaman suku, bangsa, agama, dan budaya yang diwarisi oleh bangsa Indonesia dalam sejarah mengharuskan bangsa indonesia bersatu dengan seerat-eratnya dalam keragaman itu. Keragaman itu merupakan kekayaan yang harus dipersatukan (united), tetapi tidak boleh disatukan atau diseragamkan (uniformed). Karena itu, prinsip persatuan indonesia tidak boleh diidentiikkan dengan pengertian kelembagaan bentuk negara kesatuan yang merupakan bangunan negara yang dibangun atas motto Bhinneka Tunggal Ika. Bentuk negara kita adalah Negara Kesatuan (unitary state, sedangkan persatuan Indonesia adalah prinsip dasar bernegara yang harus dibangun atas dasar persatuan (unity), bukan kesatuan (uniformity). ${ }^{40}$

Pasal 4 ayat(1)UUD1945 menyebutkan bahwa presiden memegang kendali kekuasaan tertinggi dalam suatu Negara, hal ini menjelaskan bahwa presiden memegang tampuk pemerintahan tertinggi dalam suatu ngeara kesatuan. Hal ini menunjukkan bahwa sebenarnya Negara kita menganut asas sentralistik. Dalam arti presiden memegang penuh kekuasaan dan sebagai kepala pemerintahan.

Konteks bernegara, meskipun bangsa Indonesia memilih bentuknegara kesatuan, tetapi didalamnya terselenggara suatu mekanisme yang memungkinkan tumbuh dan berkembangnya keragaman antar daerah diseluruh tanah air. Kekayaan alam dan budaya antar daerah

\footnotetext{
${ }^{39}$ Syaukani, Afan Gaffar dan M.Ryaas Rasyid, Otonomi Daerah dalam Negara Kesatuan, (Yogyakarta: Pustaka dan PUSKAP, 2002), h. 3

${ }^{40}$ Jimly Asshiddiqie, Konstitusi \& Konstitusionalisme Indonesia, (Jakarta: Konstitusi Press, 2005), h. 78
} 
tidak boleh diseragamkan dalam struktur Negara Kesatuan Republik Indonesia. Dengan perkataan lain, bentuk Negara Kesatuan Republik Indonesia diselenggarakan dengan jaminan otonomi yang seluas-luasnya kepada daerah-daerah untuk berkembang sesuai dengan potensi dan kekayaan yang dimilikinya masing-masing, tentunya dengan dorongan, dukungan, dan bantuan yang diberikan oleh Pemerintah Pusat. ${ }^{41}$

Pada sidang Tahunan MPR RI tahun 2000 (tanggal 7-18 Agustus 2000) telah dilakukan perubahan kedua UUD 1945, antara lain mengenai pembagian daerah Negara Kesatuan Republik Indonesia (NKRI) dan pemerintahan daerah. Baik struktur maupun substansi, perubahan tersebut sangat mendasar. Secara struktur, pasal 18 (lama) sama sekali diganti baru. Yang semula hanya satu pasal menjadi tiga pasal (pasal 18, pasal 18A, dan pasal 18B). Penggantian secara menyeluruh ini, berakibat pada penjelasan. Penjelasan yang selama ini 'ikut-ikutan' menjadi acuan dalam mengatur pemerintahan daerah tidak berlaku lagi. Dengan demikian, satu-satunya sumber konstitusional pemerintahan daerah adalah pasal 18, pasal 18A, dan pasal 18B.

\section{HUBUNGAN PEMERINTAH PUSAT DAN PEMERINTAH DAERAH}

Hubungan wewenang antara pemerintah pusat dan pemerintah daerah provinsi, kabupaten, kota, atau antara provinsi dan kabupaten dan kota, di atur dengan UU dengan memperhatikan kekhususan dan keragaman daerah

(Pasal 18A ayat (1) UUD 1945)

Hubungan keuangan, pelayanan umum, pemanfaatan sumber daya alam lainnya antara pemerintah pusat dan pemerintah daerah diatur dan dilaksanakan secara adil dan selaras berdasarkan UU

(Pasal 18A ayat (2) UUD 1945)

Negara mengakui dan menghormati satuan-satuan pemerintahan daerah yang bersifat khusus atau bersifat istimewa yang diatur dengan UU (Pasal 18 B ayat (1) UUD 1945)
Negara mengakui dan menghormati kesatuankesatuan masyarakat hukum adat beserta hak-hak tradisionalnya sepanjang masih hidup dan sesuai dengan perkembangan masyarakat dan prinsip negara kesatuan Republik Indonesia yang diatur dalam UU

(Pasal 18B ayat (2) UUD 1945)

Sebagai bahan perbandingan, pasal 18 UUD 1945 (sebelum amandemen) mengandung prinsip: 1) Prinsip kedaerahan; 2) Prinsip kemusyawaratan; 3) Prinsip penghargaan terhadap asal-usul daerah (kewenangan menjalankan pemerintahan, pengelolaan SDN/ SDA, penghargaan terhadap kelembagaan, dan penghargaan terhadap hukum masyarakat lokal.

Setelah diamandemennya UUD 1945, substansi pembagian daerah dalam NKRI diatur dalam pasal 18 ayat (1) UUD NRI 1945. Perubahan ini dimaksudkan untuk lebih memperjelas pembagian daerah dalam NKRI yang meliputi daerah provinsi dan dalam daerah provinsi terdapat daerah kabupaten/kota. Ketentuan pasal 18 ayat (1) ini mempunyai keterkaitan erat dengan pasal 25A mengenai wilayah NKRI.

Istilah dibagi atas (bukan terdiri atas) dalam ketentuan pasal 18 ayat (1) bukanlah istilah yang digunakan secara kebetulan. Istilah itu langsung menjelaskan bahwa negara kita adalah negara kesatuan di mana kedaulatan negara berada berada ditangan pusat. Hal ini konsisten dengan kesepakatan untuk tetap mempertahankan bentuk negara kesatuan. Berbeda dengan istilah "terdiri atas" yang lebih menunjukkan substansi federalisme karena istilah itu menunjukkan letak kedaulatan berada ditangan negara-negara bagian. ${ }^{42}$ Adapun Asas-Asas Penyelenggaraan Pemerintahan adalah: (1) Desentralisasi adalah penyerahan wewenang pemerintahan oleh Pemerintah kepada daerah otonom untuk mengatur dan mengurus sendiri urusan pemerintahannya; (2) Dekonsentrasi adalah pelimpahan wewenang pemerintahan oleh Pemerintah kepada Gubernur sebagai wakil pemerintah dan/atau kepada instansi vertikal di wilayah tertentu; (3) Tugas

\footnotetext{
${ }^{42}$ Ni’matul Huda, Hukum Pemerintahan..., h. 49 
pembantuan adalah penugasan dari Pemerintah kepada daerah dan/atau desa dari pemerintah provinsi kepada kabupaten/kota dan/atau desa serta dari pemerintah kabupaten kota kepada desa untuk melaksanakan tugas tertentu.

Desentralisasi dan otonomi daerah yang berlangsung sejak 1 Januari 2001 adalah suatu peristiwa yang menimbulkan perubahan mendasar pada hubungan pusat dan daerah, sekaligus mengubah sebagian perilaku masyarakat Indonesia yang sebelumnya hanya terfokus pada satu pusat kekuasaan saja, yaitu pemerintah pusat Jakarta. Diakui oleh Pratikno, ${ }^{43}$ desentralisasi bukan merupakan pilihan yang mudah bagi indonesia. Dengan wilayah goegrafis yang sangat luas yang terurai dalam puluhan ribu pulau, serta masyarakat yang sangat heterogen, desentralisasi memang seringkali menjadi dilema. Apresiasi terhadap keberagaman menuntut desentralisasi yang pada gilirannya melahirkan otonomi daerah. Penghargaan ini bisa menghasilkan dukungan daerah terhadap pemerintah nasional.

Didalam sistem desentralisasi, dimana ada pelimpahan kewenangan dari pemerintah pusat kedaerah, dan daerah yang menerima pelimpahan kewenangan tersebut disebut daerah otonom. Di dalam otonomi, hubungan kewenangan antara pusat dan daerah, antara lain bertalian bertalian dengan cara pembagian urusan penyelenggaraan pemerintah atau cara menentukan urusan rumah tangga daerah.

Indonesia sebagai negara kesatuan yang menerapkan sistem desentralisasi tidak lazim karena negara kesatuan biasanya menerapkan sistem sentralisitik dimana pemerintah pusat yang memegang kendali. Alasan filosofis desentralisasi dalam NKRI diantaranya sebagai berikut: ${ }^{44}$ (1) Indonesia adalah negara hukum.

\footnotetext{
${ }^{43} \mathrm{Ni}^{\prime}$ matul Huda, Hukum Pemerintahan..., h. 94

${ }^{44}$ Ibnu Tricahyo, Hand out Materi Mata Kuliah Hukum Pemerintahan Daerah, Malang: (Program Magister Ilmu Hukum FH-UB, 2010)
}

Di dalam negara hukum terdapat pemencaran kewenangan, otonom adalah salah bentuk pemencaran kewenangan; (2) Indonesia adalah negara demokrasi. Demokrasi menghendaki keterlibatan rakyat, otonomi perwujudan keterlibatan rakat dalam pemerintahan; (3) Indonesia adalah negara pluralistik. Otoda merupakan penghargaan terhadap Pluralistik; (4) Indonesia adalah negara kesejahteran. Otoda mempercepat pemenuhan kebutuhan rakyat.

Sistem pemerintahan NKRI menurut UUD 1945 memberikan keleluasaan kepada daerah untuk menyelengarakan otonomi daerah. Dalam penyelenggaraan otonomi daerah, dipandang perlu untuk lebih menekankan pada prinsip-prinsip demokrasi, peran serta masyarakat, pemerataan dan keadilan, serta memperhatikan potensi dan keanekaragaman daerah.

\section{Kesimpulan}

Pengaturan tentang pembagian kekuasaan antara pemerintahan pusat (central government) dengan pemerintahan daerah (local government) di Indonesia telah ada sejak pertama kali bangsa ini diproklamirkan tahun 1945, bahkan telah dikenal pada masa penjajahan Belanda dan Jepang. Pembagian kekuasaan tersebut menjadi dasar lahirnya distribusi kekuasaan secara horizontal antara pemerintahan pusat dan daerah. Seiring dengan adanya distribusi kekuasaan yang bersifat horizontal itupula lahir asas otonomi daerah. Otonomi daerah yang terkandung maknanya dalam pembagian daerah dalam suatu negara mengandung kesadaran bahwa daerah-daerah otonom itu memiliki sejarah kebangsaannya yang berbeda-beda. 


\section{DAFTAR PUSTAKA}

Asshiddiqie, Jimly. Konstitusi E Konstitusionalisme Indonesia. Jakarta: Konstitusi Poress, 2005

Budiharjo, Miriam. Dasar-dasar Ilmu Politik. Jakarta: Gramedia, 2000

Busroh, Abu Daud. Ilmu Negara. Jakarta: Bumi Aksara, 2001

Chalid, Pheni. Otonomi Daerah:Masalah, Pemberdayaan dan Konflik. Jakarta : Kemitraan, 2005

Cheema, G. Shabbir and Dennis A. Rondinelli, (ed.), Decentralization and Development, Policy Implementation in Developing Countries. London/New Dehli: Sage Publication, Baverly Hills, 1992

Cohen, John M. and Stepen B. Peterson, Adminitrative Desentralization. Connecticut, USA: Kumarian Press, 1999

Hatta, Mohammad. Ke arah Indonesia Merdeka (1932), jilid I. Bulan Bintang, Jakarta, 1976

Huda, Ni'matul. Hukum Pemerintahan Daerah. Bandung: Nusamedia, 2010

Hutabarat, Martin H. (eds). Hukum dan Politk Indonesia: Tinjauan Analitis Dekrit Presiden Dan Otonomi Daerah. Jakarta: Pustaka Sinar Harapan Jakarta, 1996

Isjwara, F. Pengantar Ilmu Politik. Bandung: Bina Cipta, 1980

Joeniarto, Perkembangan Pemerintahan Lokal. Jakarta: Bumi Aksara, 1992

Koesoemahatmadja, Pengantar ke Arah Sistem Pemerintahan Daerah di Indonesia. Bandung: Bina Cipta, 1979

Lubis, M. Solly. Pergeseran Garis Politik dan Perundang-undangan Mengenai Pemerintah Daerah. Alumni, Bandung, 1983

Manan, Bagir. Perjalanan Historis Pasal 18 UUD 1945. Jakarta: UNISKA, 1993

Mawhood, Philip. Local Government in the Third World. Chicester, UK: John Wisley and Sons, 1983
Muluk, M.R. Khairul Desentralisasi dan Pemerintah Daerah. Malang: Bayumedia Publishing, Cet 2, 2007

Muslimin, Amrah. Aspek-aspek Hukum Otonomi Daerah, Bandung: Alumni, 1986

Nasution, Adnan Buyung dkk, Federalisme Untuk Indonesia, Jakarta: Kompas, 1999

Nasution, Adnan Buyung. Arus Pemikiran Konstitusionalisme. Jakarta: Kasta Hasta Pustaka, 2007

Negara Kesatuan, https://id.wikipedia.org/wiki/ Negara_kesatuan, diakses tanggal 7 April 2015

Otonomi Daerah, https://id.wikipedia.org/ wiki/Otonomi_daerah, diakses tanggal 7 Maret 2015

S.N. Jha and HAL.C. Mathur (ed.), Decentralization and Lokal Politics, Sage Publications, New Delhi, Thousand Oaks, London, 1999

Situmorang, Victor. Hukum Administrasi Pemerintahan di Daerah. Jakarta:Sinar Grafika, 1994

Sujito, Irawan. Hubungan Pemerintah Pusat dan Pemerintah Daerah, Jakarta: Rineka Cipta, 1990

Surianingrat, Bayu. Desentralisasi dan Dekonsentrasi Pemerintahan di Indonesia, Suatu Analisa, Jakarta: Dewaruci Press, 1981

Syaukani, Afan Gaffar dan M.Ryaas Rasyid, Otonomi Daerah dalam Negara Kesatuan, Yogyakarta: Pustaka dan PUSKAP, 2002

Tim Lapera, Otonomi Pemberian Negara,Kajian Kritis Atas Kebijakan Otonomi Daerah. Jakarta: : Lapera Pustaka Utama, 2001

Tricahyo, Ibnu. Hand out Materi Mata Kuliah Hukum Pemerintahan Daerah. Malang: Program Magister Ilmu Hukum FHUB, 2010

Utrecht, E. Pengantar Dalam Hukum Indonesia. Jakarta: Ichtiar,1966 